\title{
Pengembangan Website JII-Analisa.com Sebagai Alat Analisis Portofolio Optimum Metode Varian Kovarian Pada Pasar Modal Syariah Di Indonesia
}

\author{
Mohammad Farhan Qudratullah, Muhammad Zakuan, dan Riyanto \\ Program Studi Matematika Fakultas Sains dan Teknologi, UIN Sunan Kalijaga, Jl. Marsda Adisucipto \\ No. 1 Yogyakarta, Indonesia
}

Korespondensi; Mohammad Farhan Qudratullah; Email: aching_lo@yahoo.com

\begin{abstract}
Abstrak
Penelitian ini bertujuan mengembangkan website JII-Analisa.com sebagai alat analisis portofolio syariah optimum metode varian kovarian. Website JII-Analisa.com dikembangkan dengan menggunakan SDLC (Sysems Development Life Cycle) yang terdiri atas 5 (lima) langkah, yaitu perencanaan rencana strategis pengembangan website, penentuan ruang lingkup pengembangan, analisis kebutuhan yang diperlukan, membuat desain dan implementasi pembuatan website serta pengujian. Secara umum terdapat 2 (dua) langkah yang dapat dilakukan untuk melakukan analisis portofolio optimum menggunakan JII.Analisa.com, yaitu pemilihan saham pembentuk portofolio menggunakan menu Analisis Saham dan perhitungan portofolio optimum. Hasil implementasi website untuk periode data 01 Januari 2014 - 28 Februari 2015 diperoleh proporsi untuk masing - masing saham pembentuk portofolio optimum adalah KLBF.JK sebesar 35\%, JSMR.JK 30\%, SSMS.JK 17\%, MPPA.JK 12\%, PTPP.JK $5 \%$, dan PWON.JK 0.2\% dengan Return yang dihasilkan sebesar $0.21 \%$, risiko sebesar $1.01 \%$ dan indeks sharpe 0.20655 .
\end{abstract}

Kata Kunci: JII-Analisa.com; Metode Varian Kovarian; Portofolio Syariah; Website

\begin{abstract}
This study aims to develop a website JII-Analisa.com as portfolio analysis tool sharia optimum variant covariance method. Website JII-Analisa.com developed using SDLC (sysems Development Life Cycle), which consists of five (5) steps, which are planning a website development strategic plan, the determination of the scope of development, requirements analysis is needed, making the design and implementation of website creation and testing, Generally, there are two (2) steps you can take to make optimum use JII.Analisa.com portfolio analysis, ie forming a portfolio stock selection using the menu Stocks Analysis and calculation of the optimum portfolio. The results of the implementation of websites for the data period January 1, 2014 - February 28, 2015 acquired the proportions for each - each forming stock is KLBF.JK optimum portfolio by $35 \%$, 30\% JSMR.JK, SSMS.JK $17 \%$, 12\% MPPA.JK, PTPP.JK 5\%, and $0.2 \%$ by Return PWON.JK generated at 12:21\%, the risk of 1:01\% and a Sharpe index is 0.20655 .
\end{abstract}

Keywords: JII-Analisa.com; Varian Covariance Method; Shariah Portfolio; Website

\section{Pendahuluan}

Sejak PT. Bursa Efek Jakarta (BEJ) menerbitkan daftar reksadana, saham, dan obligasi syariah dalam Jakarta Islamic Index (JII) pada 3 Juli 2000 yang ditindaklanjuti dengan penandatanganan nota kesepahaman antara BAPEPAM dengan Dewan Syariah Nasional - Majelis Ulama Indonesia (DSN-MUI) tentang prinsip pasar modal syariah pada tanggal 14 dan 15 Maret 2003, pasar modal syariah mengalami perkembangan cukup signifikan dan menunjukan potensi pengembangan dari tahun ke tahun. Dari Januari 2008 Maret 2013, jumlah emitem saham syariah meningkat 65\% dari 195 emitem manjadi 321 emitem. Ditinjau dari kapitalisasi, saham syariah yang tergabung dalam Jakarta Islamic Index (JII) meningkat lebih dari 4 kali lipat dari Rp. 429 triliun menjadi Rp. 1855 triliun (BEI, 2013)

Perkembangan pasar modal syariah yang cukup signifikan ini, tidak seiring dengan tingkat partisipasi masyarakat Indonesia yang mayoritas muslim. Jumlah rekening masyarakat di pasar modal 
hanya 600 ribuan atau hanya 2\% dari jumlah penduduk Indonesia (Departemen Keuangan RI, 2007). $\mathrm{Hal}$ ini, sangat jauh dari negara tetangga Malaysia yang tingkat partisipasi masyarakatnya mencapai $30 \%$ dan Singgapura sekitar $40 \%$.

Atas dasar itu, pada awal 2014, Riyanto, Qudratullah, dan Rifai [8] telah memulai merancang website analisis saham syariah yang diberi nama JII Analisa. Web JII Analisa yang telah dirancang berisi informasi seputar saham-saham syariah yang tergabung dalam JII dan telah dilengkapi dengan grafik pergerakan harga saham, grafik return, nilai mean return, nilai volatilitas, nilai resiko (VaR Historical Simulation), dan Indeks Sharpe saham-saham syariah unggulan yang tergabung dalam Jakarta Islamic Index (JII). Website ini dapat digunakan untuk menganalisis kinerja setiap emiten saham syariah. Pada pertengahan 2014, malaui program bantuan Penelitian Potensi HAKI 2014 yang diselenggarakan oleh Lembaga Penelitian dan Pengabdian Masyarakat (LP2M) UIN Sunan Kalijaga. Website tersebut telah dikembangkan oleh Qudratullah dan Riyanto dalam judul penelitian 'Pengembangan Website Analisis Saham dan Portofolio Syariah dalam Rangka Penguatan Sistem Ekonomi Islam di Indonesia' [9], yang tidak hanya menganalisa saham secara individu tetap juga mampu menganalisis kumpulan dari beberapa saham yang disebut portofolio secara serentak dan bersifat interaktif sesuai dengan keinginan investor.

Sementara itu, pada akhir 2013 Ernawati dan Qudratullah [2] telah melakukan penelitian tentang 'Analisis Portofolio Optimum menggunakan VaR dengan Metode Varians Kovarian' dengan studi kasus saham syariah di Indonesia. Sehingga untuk mengembangkan website JII - Analisa.com dan mengaplikasikan hasil penelitian teoritis di atas, maka penelitian tentang Pengembangan Website JII Analisa.com sebagai Alat Analisis Portofolio Optimum pada Pasar Modal Syariah di Indonesia' ini dilakukan.

\section{Landasan Teori}

\section{Pasar Modal Syariah di Indonesia}

Pada tanggal 3 Juli 2000, PT Bursa Efek Indonesia bekerjasama dengan PT Danareksa Invesment Management (DIM) meluncurkan indeks saham yang dibuat berdasarkan syariah Islam, yaitu Jakarta Islamic Index (JII). Indeks ini diharapkan menjadi tolak ukur kinerja saham-saham yang berbasis syariah serta untuk lebih mengembangkan pasar modal syariah. III terdiri atas 30 saham yang terpilih dari saham-saham yang sesuai dengan syariah Islam yang pemilihan sahamnya dilakukan oleh BappepamLK bekerjasama dengan Dewan Syariah Nasional (DSN) setiap 6 bulan melalui 2 tahap, yaitu seleksi syariah dan seleksi nilai volume transaksi.

\section{Return dan Risiko}

Hal mendasar dalam keputusan investasi adalah tingkat keuntungan yang diharapkan (return) dan resiko [12]. Return adalah hasil (tingkat pengembalian) yang diperoleh sebagai akibat dari investasi yang dilakukan. Ada beberapa jenis return yang biasa digunakan dalam perhitungan resiko, yaitu simple net return $\left(r_{t}\right)$ dan geometrik return atau log return $\left(R_{t}\right)$.

$$
\begin{gathered}
\left(r_{t}\right)=\frac{P_{t}-P_{t-1}}{P_{t-1}}=\frac{P_{t}}{P_{t-1}}-1 \\
R_{t}=l\left(\frac{P_{t}}{P_{t-1}}\right)=l \lambda\left(P_{t}\right)-l \lambda\left(P_{t-1}\right)
\end{gathered}
$$

Dimana,

$r_{t} \quad=$ simple net return pada periode $\mathrm{t}$

$R_{t} \quad=$ log return pada periode $\mathrm{t}$

$P_{t} \quad=$ nilai asset pada periode $\mathrm{t}$

$P_{t-1}=$ nilai asset pada periode $\mathrm{t}-1$

Dari persamaan (1) dan (2) dapat diperoleh hubungan log return dan simple net return, yaitu: $R_{t}=$ $l i\left(r_{t}+1\right)$ [6]. Jika terdapat $\mathrm{T}$ observasi, maka ekspetasi return yang diharapkan dapat dirumuskan sebagai berikut: 


$$
E\left(R_{t}\right)=\bar{R}=\frac{\sum_{t=1}^{T} R_{t}}{T}
$$

\section{Indeks Sharpe}

Indeks Sharpe merupakan pengukur kinerja saham yang dihitung dengan membagi premi risiko dengan risiko saham (standar deviasi). Premi risiko merupakan selisih antara return saham dengan akiva bebas risiko. Dari perbandingan tersebut diketahui bahwa harga indeks berbanding lurus dengan premi risiko serta berbanding terbalik dengan risiko (standar deviasi). Indeks Sharpe dapat diformulasikan sebagai berikut.

Keterangan

$$
S h=\frac{\bar{R}_{t}-S I_{E}}{S d_{t}}
$$

$S h=$ Nilai indeks sharpe

$\bar{R}_{t} \quad=$ Rata-rata nilai return pada periode tertentu

$S I_{t}=$ Rata-rata bunga bebas risiko pada periode tertentu

$S d_{t}=$ Standar deviasi periode tertentu

\section{Portofolio Optimum dengan Metode Varian Kovarian}

Portofolio merupakan gabungan dari berbagai instrument investasi yang dipegang oleh investor. Dalam berinvestasi, seorang invertor berusaha memaksimalkan tingkat pengembalian dari portofolio yang dibentuk dengan tingkat resiko tertentu atau tingkat resiko yang minimum dengan tingkat pengembalian tertentu (Fabozzi, 1995). Portofolio yang demikian itu disebut portofolio yang efisien atau optimum.

Salah satu metode penentuan bobot portofolio optimum adalah metode varian kovarian [5]. Berikut persamaannya:

$$
w=\frac{\Sigma^{-1} 1_{N}}{1_{N}^{T} \Sigma^{-1} 1_{N}}
$$

\section{HTML (Hyper Text Markup Language)}

HTML adalah kependekan dari Hyper Text Markup Language. Dokumen HTML adalah file teks murni yang dapat dibuat dengan editor teks sembarang, dokumen ini dikenal sebagai web page. Dokumen HTML disusun oleh elemen-elemen pembentuk dokumen HTML, diantaranya adalah: head, body, table, paragraph, dan list. Format penulisan suatu dokumen HTML digunakan suatu tag, dimana dimulai dengan tanda kurang dari $(<)$ diikuti nama elemen dan tanda lebih dari $(>)$. Format tag tersebut biasanya diikuti dengan tag penutup dengan format tanda kurang dari $(<)$, garis miring (/), nama tag dan tanda lebih dari $(>)[10]$. Berikut ini contoh penulisan dokumen HTML:

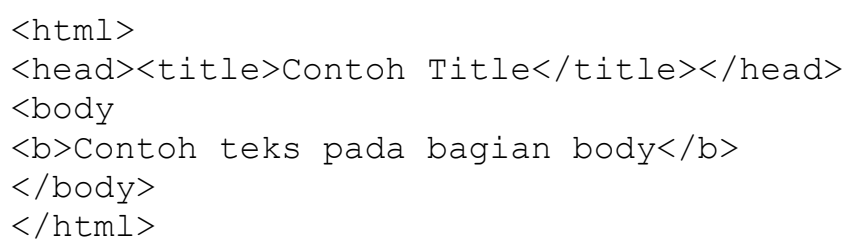

\section{PHP (Hypertext Preprocessor)}

PHP sering kali digunakan dalam pembuatan web dinamis. Web dinamis adalah web yang kontennya dapat diubah dengan mudah tanpa harus melakukan pemeliharaan program secara terus menerus untuk mengikuti setiap perubahan yang terjadi. PHP merupakan program server-side, yaitu script yang membuat dokumen HTML secara on the fly. PHP mendukung aplikasi web database skala besar [7]. Ada beberapa alasan yang membuat PHP menjadi pilihan, yaitu: PHP merupakan software yang open source, mempunyai kemampuan mengeksekusi secara cepat ke database, dan fleksibel dalam platform dan sistem operasi. 
Berikut ini adalah contoh yang menjelaskan PHP sebagai script yang disisipkan:

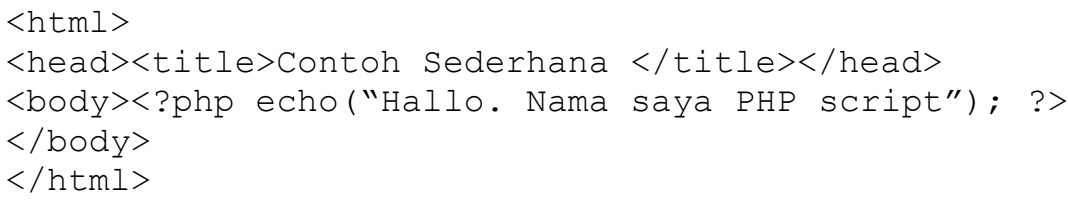

\section{Metode Penelitian}

Untuk menjawab permasalah penelitian ini, terdapat 4 (empat) langkah yang perlu dilakukan sampai penarikan kesimpulan, yaitu: studi literatur, pengembangan sistem website, pengujian sistem, dan implementasi sistem.

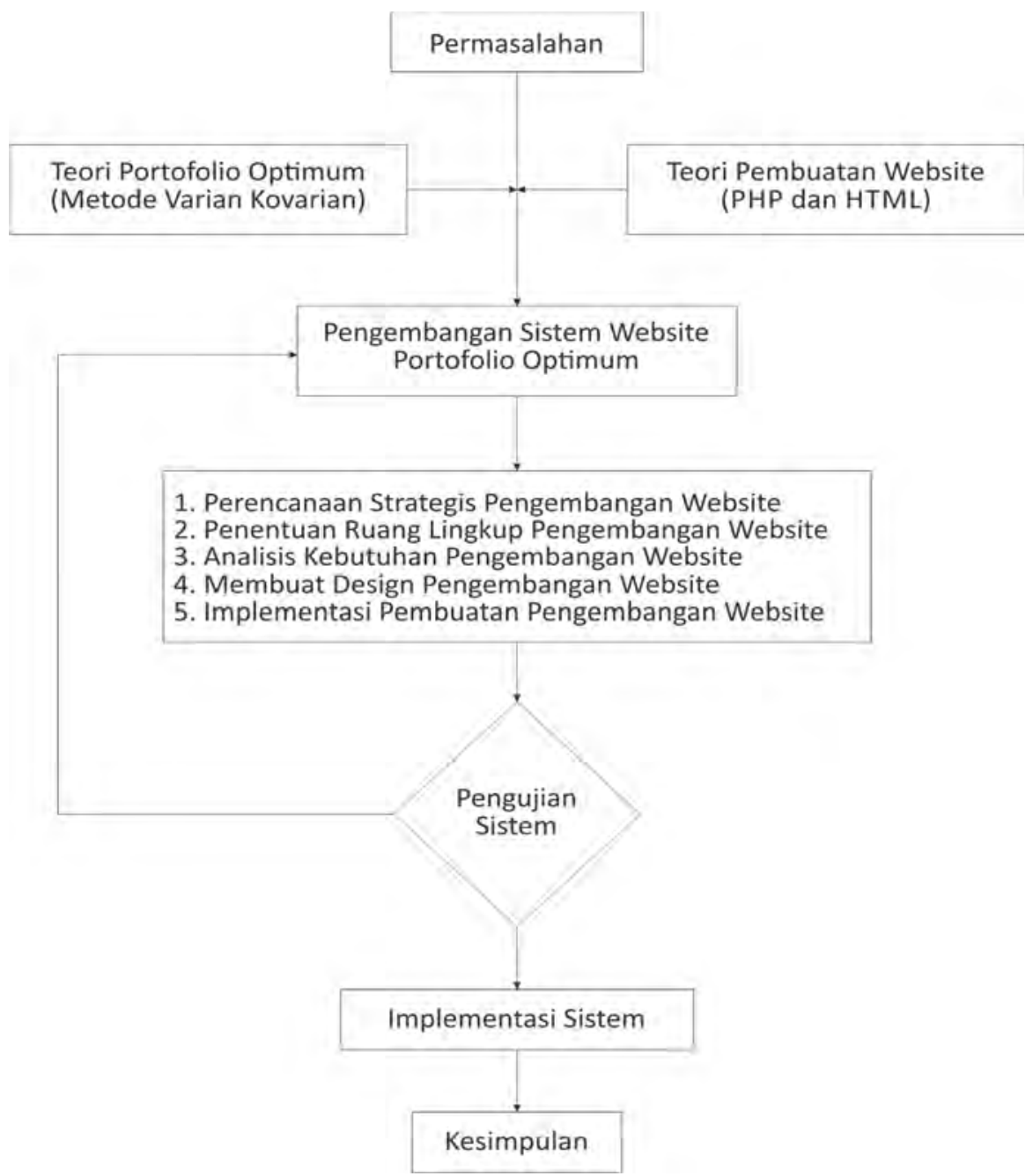

Gambar 1 Diagram Alir Penelitian.

\section{Hasil dan Pembahasan}

\section{Hasil Implementasi Sistem}

1. Hasil Implementasi Halaman Analisis Saham

Halaman analisis saham berfungsi untuk menganalisis kinerja dari semua saham yang terdapat dalam database dengan menggunakan indeks Sharpe, dalam rangka memilih saham pembentuk portofolio. 


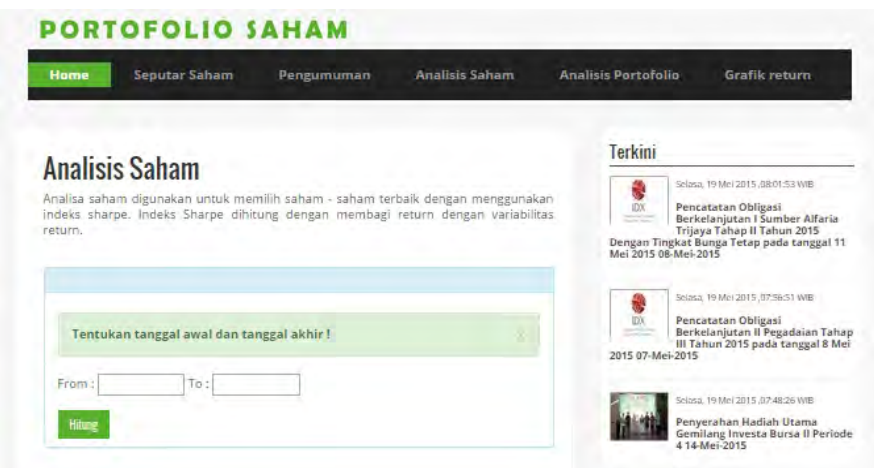

Gambar 2 Implementasi Halaman Analisis Saham.

2. Implementasi Halaman Analisis Portofolio.

Halaman analisis portofolio berfungsi untuk menganalisa portofolio dari saham saham yang dipilih oleh user sehingga dihasilkan risiko portofolio yang minimum dengan tingkat keuntungan tertentu.

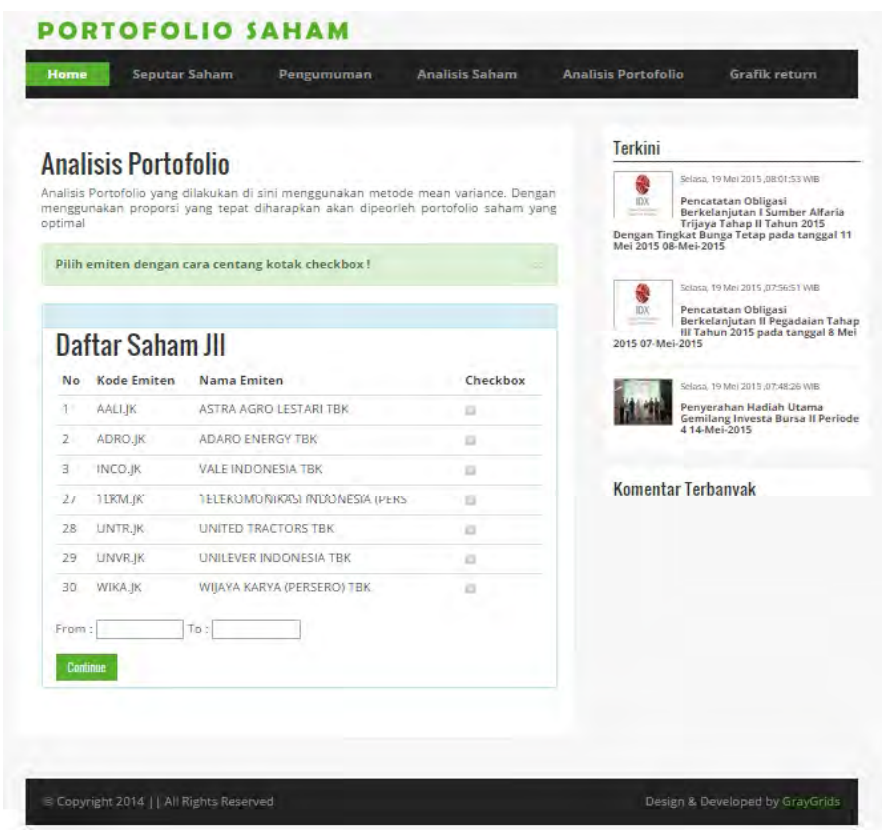

Gambar 3 Implementasi Halaman Analisis Portofolio.

\section{Pengujian Sistem}

Pengujian dilakukan guna menguji kemampuan sistem dalam membentuk portofolio optimal saham. Pengujian yang dilakukan pada penelitian ini menggunakan metode black box dengan memfokuskan pada usabilitas dari sistem. Uji coba data yang digunakan dalam pengujian ini adalah dengan membandingkan hasil dari data yang diolah oleh sistem dengan data yang dihitung secara manual menggunakan bantuan software Microsoft Excel.

1. Pengujian Sistem Analisis Saham

Sebagai sampel dalam pengujian ini hanya akan ditampilkan screenshot nilai return, risiko dan indeks sharpe saham AALI.JK dari tanggal 1 Januari 2015 sampai 31 Januari 2015. 


\begin{tabular}{|c|c|c|c|c|c|c|c|}
\hline \multicolumn{3}{|c|}{ F3 } & $(3) \quad f$ & \multicolumn{4}{|c|}{$=$ ROUND(STDEV $(\mathrm{C} 2: \mathrm{C} 22), 5)$} \\
\hline$P$ & A & B & C & D & E & $\mathrm{F}$ & G \\
\hline 1 & Tanggal & adjclose & Return re & sasian & & & \\
\hline 2 & $1 / 30 / 2015$ & 22780 & 0.002156 & & ER & -0.00185 & \\
\hline 3 & $1 / 29 / 2015$ & 22731 & $1-0.02005$ & & RISIKO & 0.0178 & \\
\hline 4 & $1 / 28 / 2015$ & 23196 & $\begin{array}{ll}5 & -0.02472\end{array}$ & & INDEX SHARPE & -0.10393 & \\
\hline 5 & $1 / 27 / 2015$ & 23784 & $\begin{array}{ll}4 & 0.031889\end{array}$ & & & & \\
\hline 6 & $1 / 26 / 2015$ & 23049 & -0.01982 & & & & \\
\hline 7 & $1 / 23 / 2015$ & 23515 & 0 & & & & \\
\hline 8 & $1 / 22 / 2015$ & 23515 & -0.00722 & & & & \\
\hline 9 & $1 / 21 / 2015$ & 23686 & $5-0.01329$ & & & & \\
\hline 10 & $1 / 20 / 2015$ & 24005 & 0 & & & & \\
\hline 11 & $1 / 19 / 2015$ & 24005 & $5-0.00908$ & & & & \\
\hline 12 & $1 / 16 / 2015$ & 24225 & -0.00904 & & & & \\
\hline 13 & $1 / 15 / 2015$ & 24446 & 50.002008 & & & & \\
\hline 14 & $1 / 14 / 2015$ & 24397 & -0.03858 & & & & \\
\hline 15 & $1 / 13 / 2015$ & 25376 & 0.003877 & & & & \\
\hline 16 & $1 / 12 / 2015$ & 25278 & $\begin{array}{ll}3-0.00676 \\
\end{array}$ & & & & \\
\hline 17 & $1 / 9 / 2015$ & 25450 & 0.029739 & & & & \\
\hline 18 & $1 / 8 / 2015$ & 24715 & 0.021239 & & & & \\
\hline 19 & $1 / 7 / 2015$ & 24201 & 0.016464 & & & & \\
\hline 20 & $1 / 6 / 2015$ & 23809 & -0.01518 & & & & \\
\hline 21 & $1 / 5 / 2015$ & 24176 & 0.00407 & & & & \\
\hline 22 & $1 / 2 / 2015$ & 24078 & 0.013384 & & & & \\
\hline 23 & $1 / 1 / 2015$ & 23760 & & & & & \\
\hline 24 & & & & & & & \\
\hline
\end{tabular}

Gambar 4 Perhitungan Analisis Saham AALI.JK.

Gambar 4 merupakan hasil perhitungan manual dan gambar 5 merupakan hasil analisis website, tampak bahwa hasil perhitungan menggunakan manual dan menggunakan website untuk saham AALI.JK adalah sama.

\begin{tabular}{|c|c|c|c|c|c|c|c|c|c|}
\hline No & Kode Emiten & Return & Risiko & Nilai Indeks & 16 & KLBF.JK & 0.00096 & 0.01009 & 0.09514 \\
\hline 1 & MPPA.JK & 0.01091 & 0.02866 & 0.38067 & 17 & LPPF.JK & 0.00191 & 0.02393 & 0.07982 \\
\hline 2 & WSKT.JK & 0.00761 & 0.02228 & 0.34156 & 18 & WIKA.JK & 0.00096 & 0.01625 & 0.05908 \\
\hline 3 & UNVR.JK & 0.00509 & 0.01755 & 0.29003 & 19 & SCMA.JK & -0.00084 & 0.02663 & -0.03154 \\
\hline 4 & AKRA.JK & 0.00648 & 0.02297 & 0.28211 & 20 & PWON.JK & -0.00107 & 0.0303 & -0.03531 \\
\hline 5 & BSDE.JK & 0.00561 & 0.02251 & 0.24922 & 21 & SSMS.JK & -0.00036 & 0.00989 & -0.0364 \\
\hline 6 & PTPP.JK & 0.00449 & 0.01812 & 0.24779 & 22 & LSIP.JK & -0.00111 & 0.01952 & -0.05686 \\
\hline 7 & LPKR.JK & 0.0053 & 0.02139 & 0.24778 & 23 & TLKM.JK & -0.00054 & 0.00905 & -0.05967 \\
\hline 8 & INDF.JK & 0.00565 & 0.02574 & 0.2195 & 24 & ADRO.JK & -0.00171 & 0.01812 & -0.09437 \\
\hline 9 & ICBP.JK & 0.0052 & 0.02722 & 0.19104 & 25 & AALL.JK & -0.00185 & 0.0178 & -0.10393 \\
\hline 10 & SMRA.JK & 0.00421 & 0.02426 & 0.17354 & 26 & INCO.JK & -0.00219 & 0.01835 & -0.11935 \\
\hline 11 & ASRIJJK & 0.00312 & 0.02039 & 0.15302 & 27 & SILOJKK & -0.00102 & 0.00843 & -0.121 \\
\hline 12 & ITMG.Jk & 0.00452 & 0.03028 & 0.14927 & 28 & INTP.JK & -0.0036 & 0.02688 & -0.13393 \\
\hline 13 & ASIIIJK & 0.00283 & 0.01913 & 0.14794 & 29 & SMGR.JK & -0.00476 & 0.02304 & -0.2066 \\
\hline 14 & UNTR.JK & 0.00156 & 0.01226 & 0.12724 & 30 & PGAS.JK & -0.00804 & 0.01663 & -0.48346 \\
\hline
\end{tabular}

Gambar 5 Hasil Output Sistem Analisis Saham.

2. Pengujian Sistem Analisis Saham

Berdasarkan hasil pada langkah analisis saham di atas diperoleh 5 saham dengan indeksSharpe tertinggi yaitu saham MPPA.JK, WSKT.JK, UNVR.JK, AKRA.JK, dan BSDE.JK yang digunakan untuk pengujian.

- Perhitungan Proporsi Portofolio

Langkah pertama dalam perhitungan proporsi adalah dengan mencari return realisasian masing masing saham pembentuk portofolio. Langkah kedua setelah diperoleh return realisasian adalah membentuk matriks varian kovarian. Langkah ketiga setelah diperoleh matriks varian kovarian 
adalah mencari invers matriks varian kovarian. Langkah keempat Setelah diperoleh invers matriks varian kovarian maka dihitung proporsi untuk masing-masing saham.

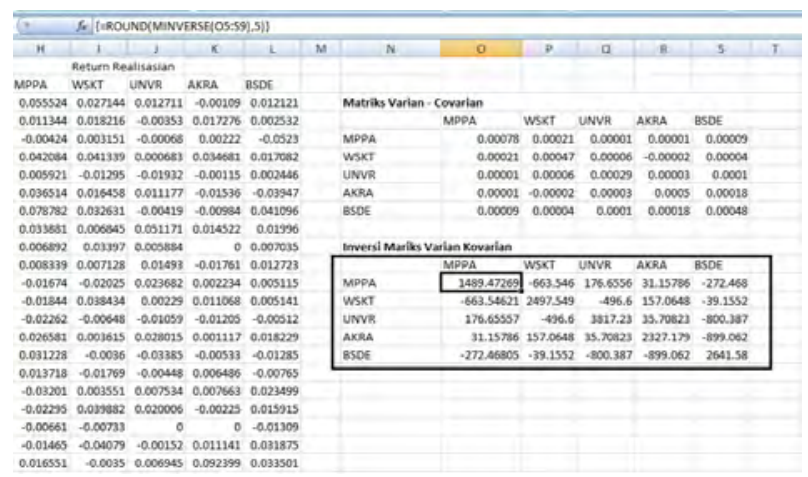

Gambar 6 Perhitungan Manual Langkah 1-3.

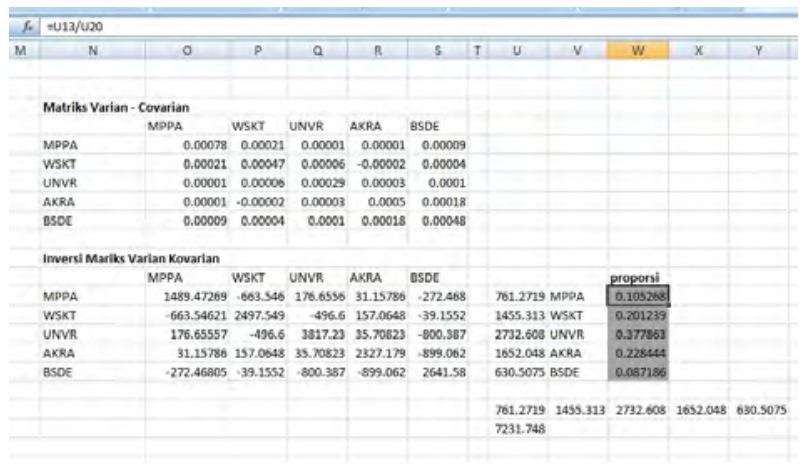

Gambar 7 Perhitungan Manual Proporsi.

\begin{tabular}{|c|c|c|}
\hline No & Kode Emiten & Proporsi \\
\hline 1 & MPPA.JK & 0.1052680256 \\
\hline 2 & AKRA.JK & 0.2284437819 \\
\hline 3 & WSKT.JK & 0.2012394399 \\
\hline 4 & BSDEJKK & 0.0871860394 \\
\hline 5 & UNVR.JK & 0.3778627132 \\
\hline Total & & 1 \\
\hline
\end{tabular}

Gambar 8 Hasil Output Proporsi Saham Sistem.

Gambar 7 dan 8 di atas menunjukkan adanya kesamaan antara perhitungan manual dan website. Hal ini dapat disimpulkan bahwa sistem dapat membentuk portofolio saham yang optimal.

- Return dan Risiko Portofolio

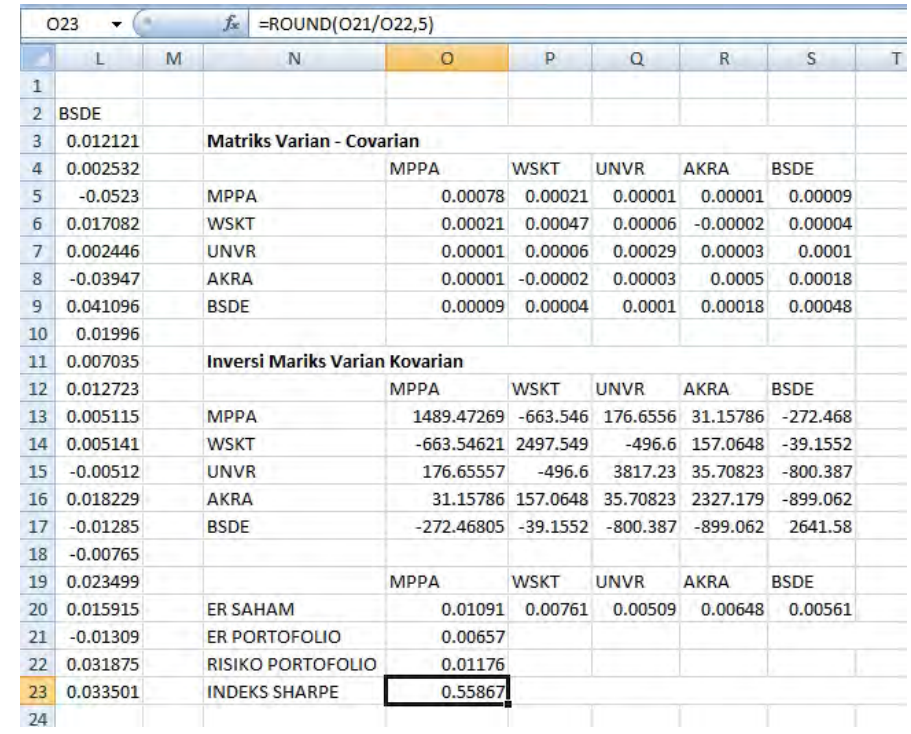

Gambar 9 Perhitungaan Manual Return, Risiko, Indeks Sharpe Portofolio. 


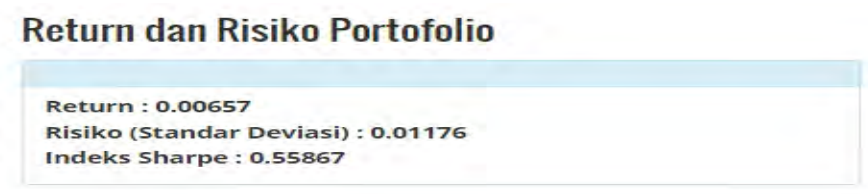

Gambar 10 Hasil Perhitungan Sistem Portofolio.

Tampak bahwa perhitungan manual untuk return, resiko, dan indeks Sharpe dan perhitungan sistem sama.

\section{Studi Kasus}

Pada studi kasus ini, akan dianalisis portofolio optimum saham syariah yang tergbung dalam Jakarta Islamic Index periode tanggal 1 Januari 2014 sampai tanggal 28 Februari 2015.

1. Pemilihan Saham Pembentuk Portofolio Langkah pertama yang dilakukan adalah memilih saham-saham pembentuk portofolio dengan meemilih menu Analisis Saham (Gambar 11) yang dilanjutkan dengan mengisi periode data yang akan dianalisis (Gambar12) dan klik tombol Hitung.

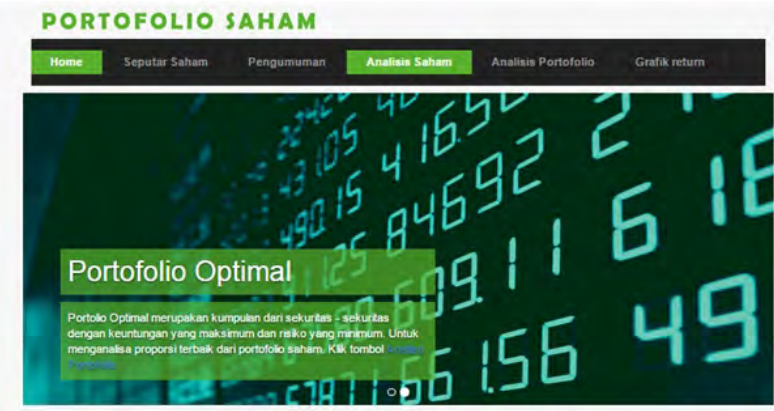

Gambar 11 Menu Analisis Saham.

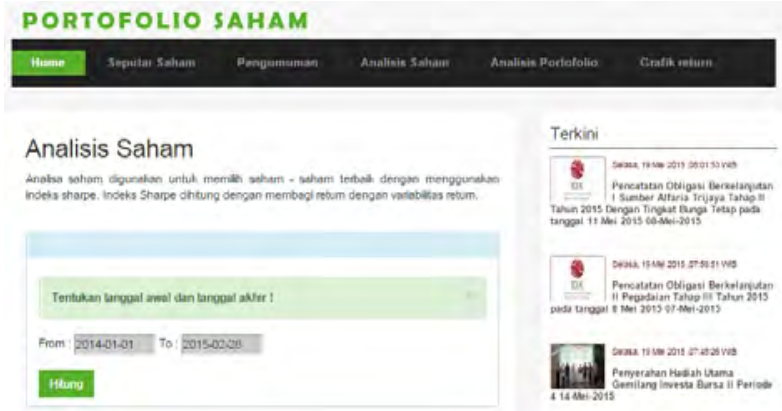

Gambar 12 Setting periode data Analisis Saham.

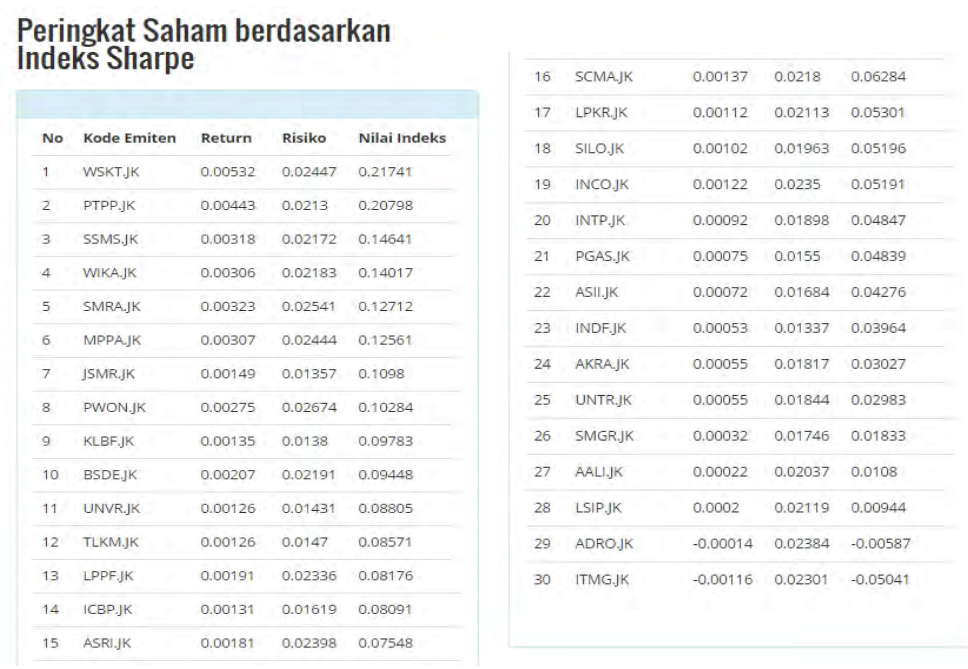

Gambar 13 Peringkat Saham berdasarkan Index Sharpe.

Dari hasil tersebut diketahui 10 saham dengan indeks Sharpe terbaik adalah WSKT.JK, PTPP.JK, SSMS.JK, WIKA.JK, SMRA.JK, MPPA.JK, JSMR.JK, PWON.JK, KLBF.JK, dan BSDE.JK. Kesepuluh saham inilah yang akan dijadikan saham pembentuk portofolio syariah. 
2. Analisis Portofolio

Langkah kedua adalah melakukan analisis portofolio optimum dengan memilih menu Analisis Portofolio (gambar 11), maka muncul daftar saham syariah dan beri tanda untuk saham-saham yang dimasukan dalam portofolio yang dilanjutkan dengan mengisi periode data dan klik Continue.

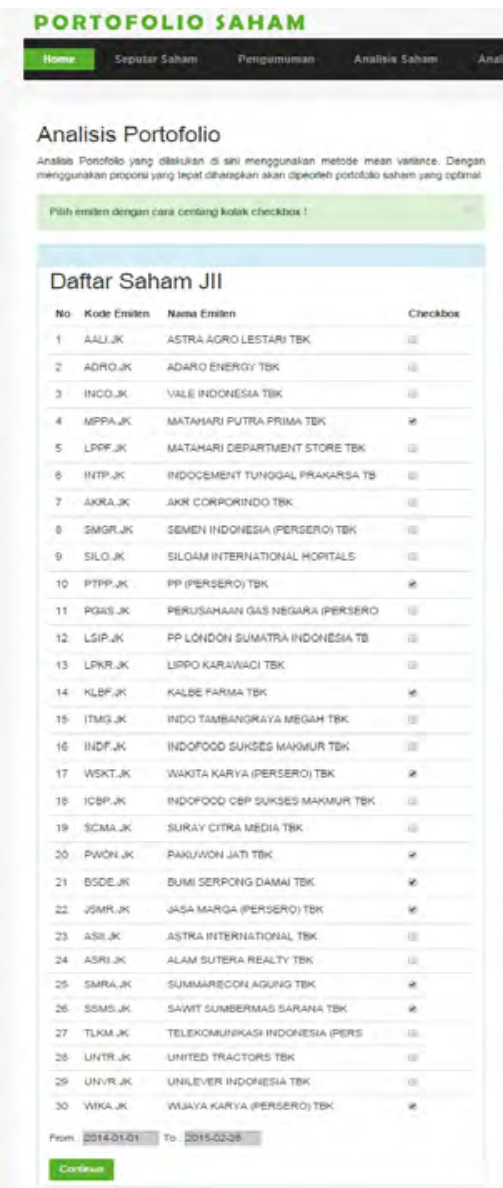

Gambar 14 Pemilihan Portofolio.

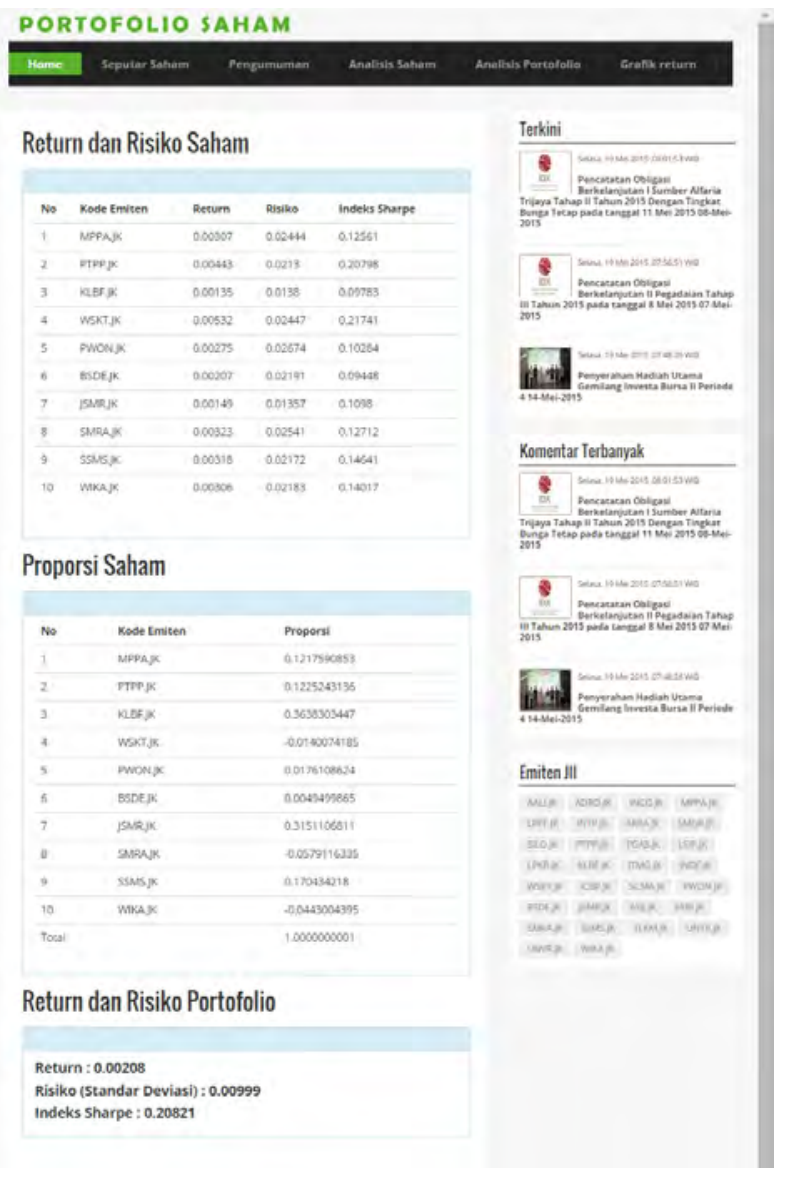

Gambar 14 Output Analisis Portofolio.

Hasil analisis portofolio dari sistem menghasilkan output return dan risiko saham, proporsi saham, return portofolio optimal, dan risiko portofolio optimal saham. Dari hasil analisis portofolio, terdapat 3 saham dengan proporsi negatif yaitu saham WSKT.JK, SMRA.JK, dan WIKA.JK. Dikarenakan short sales tidak dibolehkan maka saham saham dengan proporsi negatif dikeluarkan dari portofolio saham. Sehingga akan dilakukan analisis portofolio kedua tanpa mengikutsertakan saham saham dengan proporsi negatif pada langkah sebelumnya. Sehingga diperoleh output akhir sebagai berikut:
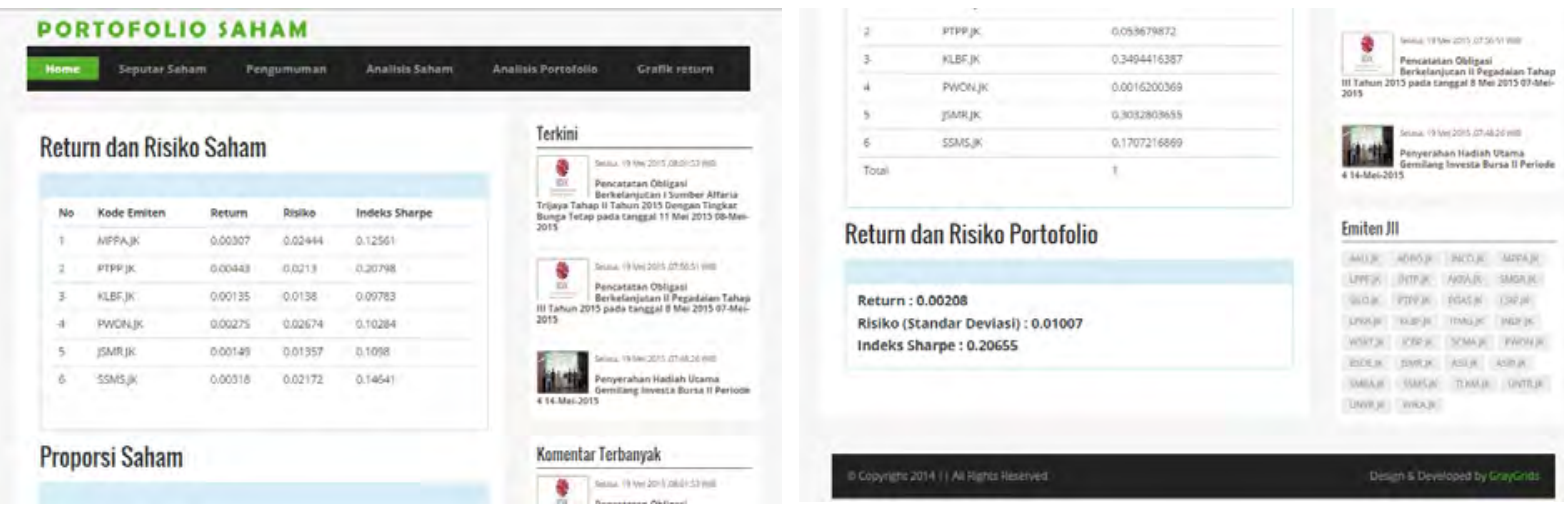

Gambar 15 Output Akhir Analisis Portofolio. 
Hasil analisis portofolio optimal saham menunjukkan nilai proporsi untuk masing masing saham adalah KLBF.JK sebesar 0.35, JSMR 0.30, SSMS.JK 0.17, MPPA.JK 0.12, PTPP.JK 0.05, dan PWON.JK 0.002. Return yang dihasilkan dari portofolio optimal saham ini adalah sebesar 0.00208 dengan risiko sebesar 0.01007 dan indeks sharpe 0.20655. Dengan demikian jika seorang investor menginvestasikan dananya sebesar Rp. 200.000.000,- maka keuntungan yang dapat diperoleh dari investasinya sebesar Rp. 200.000.000,- $\times 0.00208=416.000$ dengan risiko sebesar Rp. 200.000.000,- $\times 0.01007=$ Rp. 2.014.000,-

\section{Kesimpulan dan Saran}

\section{Kesimpulan}

Berikut beberapa kesimpulan yang diperoleh:

1. Website JII-Analisa.com berhasil dikembangkan sebagai alat analisis portofolio optimum metode varian kovarian dengan menggunakan SDLC (Sysems Development Life Cycle) yang terdiri atas 5 (lima) langkah, yaitu perencanaan rencana strategis website yang akan dibangun, penentuan ruang lingkup website, analisis kebutuhan website yang diperlukan, membuat desain baik desain tampilan untuk user maupun administrator menggunakan usecase diagram, dan implementasi pembuatan website, serta telah melalui proses pengujian sistem.

2. Hasil analisis portofolio optimal saham menunjukkan nilai proporsi untuk masing masing saham adalah KLBF.JK sebesar 0.35, JSMR 0.30, SSMS.JK 0.17, MPPA.JK 0.12, PTPP.JK 0.05, dan PWON.JK 0.002. Return yang dihasilkan dari portofolio optimal saham ini adalah sebesar 0.00208 dengan risiko sebesar 0.01007 dan indeks Sharpe 0.20655. Dengan demikian jika seorang investor menginvestasikan dananya sebesar Rp. 200.000.000,- maka keuntungan yang dapat diperoleh dari investasinya sebesar Rp. 200.000.000,- $\times 0.00208=416.000$ dengan risiko sebesar Rp. 200.000.000,- $\times 0.01007=$ Rp. 2.014.000,-.

\section{Saran}

Website JII-Analisa.com ini telah mampu menganalisis saham baik secara individu maupu secara bersama-sama dalam bentuk portofolio dan portofolio optimum mengguakan metode varian kovarian. Namun, terdapat beberapa hal yang dapat dikembangkan dalam penelitian selanjutnya, seperti pengembangan sebagai alat analisis tipologi saham dalam rangka pemilihan saham pembentuk portofolio optimum, pengembangan sistem analisis user, pengembangan menu dan informasi lainnya dalam rangka pembelajaran saham syariah, dan lain sebagainya.

\section{Ucapan Terimakasih}

Atas terselesainya penelitian ini, peneliti mengucapkan terima kasih kepada Lembaga Penelitian dan Pengabdian Masyarakat (LP2M) UIN Sunan Kalijaga Yogyakarta yang telah memberikan hibah penelitian, Program Studi Matematika Fakutas Sains dan Teknologi UIN Sunan Kalijaga atas dukungannya dan Laboratorium Matematika Laboratorium Terpadu UIN Sunan Kalijaga sebagai tempat pelaksanaan penelitian.

\section{Referensi}

[1] Batuparan, D.S. (2000). BEI NEWS: Mengapa Risk Management? Edisi 4. Jakarta: Bursa Efek Indonesia (BEI)

[2] Ernawati, R.D, dan Qudratullah, M.F., (2013). Analisis Portofolio Optimum menggunakan VaR dengan Metode Varians Kovarian, Studi Kasus: Saham Syariah. UIN Sunan Kalijaga Yogyakarta

[3] Halim, A, 2003. Analisis Investasi. Jakarta: Salemba Empat

[4] Hariyanto, 2004. Bambang, Sistem manajemen basisdata. Bandung: Informatika

[5] Jogiyanto, 2010. Teori Portofolio dan Analisis Investasi. Yogyakarta: BPFE-Yogyakarta.

[6] Jorion, P. (2007). Value at Risk: The New Benchmark for Managing Financial Risk. McGraw-Hill, New York

[7] Kadir, A. (2005). Pengenalaan Teknologai Informasi. Yogyakarta: Andi Offset

[8] Qudratullah, M.F., (2014). Pengembangan Website Analisis Saham Dan Portofolio Syariah dalam Rangka Penguatan Sistem Ekonomi Islam di Indonesia'. Lemlit UIN Sunan Kalijaga Yogyakarta 
[9] Qudratullah, M.F., dan Riyanto (2015). Rancang Bangun Website Analisis Return dan Resiko Saham Syariah di Indonesia. Integrated Lab Journal: Volume 03, No. 01, April 2015. Hal: 25-34

[10] Sidik, B. (2009). Pemrograman Web dengan HTML. Bandung: Informatika Bandung

[11] Sudarsono, H. (2003), Bank dan Lembaga Keuangan Syariah, Edisi 2. Penerbit Ekonisia Kampus Fakultas FE UII Yogyakarta

[12] Tandelilin, E. (2001). Analisis Investasi dan Managemen Portofolio. Yogyakarta: BPFE. 